\title{
Työtieteellinen täydennyskoulutusohjelma
}

\author{
Professori Juhani Kirjosen tekemä matka Yhdysvaltoihin ja \\ siellä tehdyt haastattelut liittyvät osittain Tampereen yliopistossa \\ ja Jyväskylän yliopistossa toteutetun työtieteellisen täydennys- \\ koulutusohjelman kehittämiseen. \\ Ensimmäisen työtieteellisen täydennyskoulutusohjelman \\ vaiheet ovat seuraavat:
}

Aloite työtieteellisen täydennyskoulutuksen järjestämiseksi tuli vuonna 1985 valtionvarainministeriön järjstelyosaston koulutustoimistosta. Toimiston tehtäviin on kuulunut suunnitella valtionhallinnon yleistä henkilöstön kehittämispolitiikkaa, mm. koulutusta. Nyttemmin toimiston tehtävät on tältä osin siirretty pääosin valtionhallinnon kehittämiskeskukselle.

1980-luvun alussa istunut ns. Heiskasen komitea käsitteli valtionhallinnon johdon koulutustarpeita ja esitti suosituksenaan $\mathrm{mm}$. keskijohdon täydennyskoulutuksen tehostamista. Näissä suosituksissa mainittiin kolme pääaluetta: talous ja budjetointi, johtaminen ja hallinto sekä työympäristökysy. mykset, joilla viitattiin erityisesti työelämän psykologisiin ja sosiaalisiiin tekijöihin. Syynä siihen, että viimeksi mainittuja myös korostettiin, oli komitean huoli nähtävissä olevista suurista muutoksista työelämässä ( $\mathrm{mm}$. uusi tietotekniikka) ja virkamiesten koulutuksellisista puutteista ja vanhentuneista pätevyyksistä suhteessa muutosten asettamiin uusiin sopeutumisvaatimuksiin.

Lisäksi katsottiin, että täydennyskoulutuksessa tulisi käyttää hyväksi tietoa, jota psykologinen, sosiologinen, pedagoginen ja muu sosiaalitieteellinen tutkimus työelämässä oli viime aikoina tuottanut.

Komitea suuntasi huomiota nimenomaan keskijohdon koulutustarpeisiin, koska näissä tehtävissä toimivat kohtaavat ensimmäisinä esimerkiksi uuden tekniikan ja tietojärjestelmien suunnitteluun ja käytännönottoon liittyvät ongelmat. Samalla he kohtaavat niihin liittyvät organisatoriset vaikeudet: toimien suunnittelun, henkilöstön valinnan, koulutuksen jne. vastaavat, jotka liittyvät kiinteästi henkilöstöhallintoon.
Komitea nimesi Tampereen ja Jyväskylän yliopistot paikoiksi, joissa olisi koulutuksen järjestämisen kannalta hyvin soveltuva tiedepohja ja riittävästi kokeneita tutkijoita opettajiksi.

O O O

Suunnitteluryhmä aloitti työnsä kesäkuussa 1985 Tampereen yliopistossa. Ryhmään kuului kaksi henkilöä Tampereen ja Jyväskylän yliopistoista, kaksi koulutustoimistosta (VVM) ja yksi työvoimaministeriöstä.

Ensimmäisten kokousten jälkeen ja pedehdyttyään taustamateriaaliin ryhmä totesi, että täydennyskoulutuksen tarve näytti todelliselta. Sen sijaan virkamiesten opiskelumotiivaatio oli alhainen tai vaihteleva. Lisäksi valtionhallinnon virastojen resurssit olivat melko rajoitettuja. Kuitenkin päätettiin aloittaa kokeileva, tieteidenvälinen ohjelma. Sen alustava nimi oli "Valtionhallinnon johdon täydennyskoulutusohjelma: ihminen ja työ yhteiskuntatieteiden ja psykologian näkökulmista".

Tampereen yliopiston täydennyskoulutuskeskus vastasi ohjelman järjestämisestä ja tarjosi hallinnolliset puitteet sen toteuttamiseksi (Karin Filander). Ohjelman vetäjäksi valittiin Juhani Kirjonen. Valtiovarainministeriö maksoi osan kustannuksista ja lopuista vastasivat virastot, joista osallistujat tulivat.

Varsinaiseen ohjelmaryhmään kuului seitsemän jäsentä, jotka edustivat molempia yliopistoja sekä eri tieteenaloja: psykologiaa, sosiologiaa, sosiaalipolitiikkaa, hallintotieteitä, aikuiskasvatusta ja sosiaalilääketiedettä.

Ryhmä jakoi ohjelman neljään jaksoon: orientoitumiseen, perusteisiin, suomalaiseen 
työelämän tutkimukseen sekä tutkimustiedon soveltamiseen.

Teoreettisesti ohjelma liittyi kokemusperäisen oppimisen ideoihin (Kolb, jonka haastattelu aiheesta julkaistaan Aikuiskasvatuksen numerossa 2/90). Se tarjosi oppivan ympäristön, jossa oli mahdollista seurata oppimiskehää: konkreettisista kokemuksista reflektiivisiin analyyseihin, käsitteellisiin yleistyksiin, ajatusten testaamiseen uusissa tilanteissa jne. ja edelleen takaisin konreettiselle tasolle.

Ohjeissa korostettiin osallistujien oman aktiivisen työskentelyn tärkeyttä aineiston keräämisessä, analysoimisessa ja yhdistämisessä. Siten yritettiin lähestyä reflektiivisen ajattelun kolmatta tasoa (Mezirow). Opetus liitettiin myös sellaisiin teoreettisiin ideoihin, jotka liittyvät organisaatiokulttuuriin ja sen rooliin yksilöllisen oppimisprosessin helpottamisessa tai estämisessä. Näin pyritään avaamaan yksi näkökulma laajaan keskusteluun, joka liittyy viimeaikaisiin ajatuksiin organisaation kehittämisestä (ks. Argyris, Bennis, Björn-Andersen, Gustavsen, Schön jne.).

\section{Ohjelman periaatteet olivat:}

1. kuhunkin teemaan liittyvien tieteenalojen yhdistäminen (tieteidenvälinen lähentyminen),

2. huomion kiinnittäminen muutoksiin työssä ja organisaatioissa sekä muutoksen tutkimisen tieteellisiin menetelmiin,

3. ajattelun ja toiminnan vuorovaikutuksen korostaminen oppimisessa ja tekemisessä: mukaan lukien osallistujien omat harjoitustyöt, jotka pyrkivät yhdistämään opiskelun ja päivittäisen työkäytännön sekä tukemaan opiskelumotivaatiota.

Seuraavat teemat läpäisivät koko ohjelman:

a) työelämän muutosprosessit, tieteellinen tieto työssä ja uuden tiedon tuottamisen menetelmät,

b) työn suunnittelu ja organisaation kehittäminen,

c) työorganisaatioiden ja niiden johtamisen rakenne ja muutos sekä

d) työn sosiaaliset, psyykkiset ja terveydelliset vaikutukset.

Ohjelman pääasialliseksi kohderyhmäksi määriteltiin henkilöstöhallinnon linjajohtajat, tietojärjestelmien kehittämisen, rationalisoinnin yms. kehittämisen asiantuntijat, jotka tarvitsevat tietoa ihmisen, työn ja organisaation suhteista. Ensimmäinen tiedotus lähetettiin kaikille valtionhallinnon virastoille joulukuun 1985 alussa ja ohjelma alkoi maaliskuussa 1986, jolloin ensimmäinen yhteyskirje lähetettiin valituille osallistujille.

Nykyään suunnittelemme toisen ohjelman aloittamista lukuvuoden 1990-91 aikana. Tarkoituksemme on suunnitella ohjelmaan liittyviä tutkimuksia seuraavilta alueilta: organisaatiokulttuuri, yksilöllinen ja organisatorinen oppiminen, koulutusmotivaatio sekä kommunikaatio tieteellisten ja työelämän asiantuntijoiden välillä. 